\title{
BLOOD TRANFUSION IN CRITICALLY ILL PATIENTS: STATE OF THE ART
}

\author{
Ludhmila Abrahão Hajjar, Jose Otávio Costa Auler Junior, Luciana Santos,
} Filomena Galas

Hajjar LA, Auler Junior JOC, Santos L, Galas F. Blood tranfusion in critically ill patients: state of the art. Clinics. 2007;62(4):507-24.

Anemia is one of the most common abnormal findings in critically ill patients, and many of these patients will receive a blood transfusion during their intensive care unit stay. However, the determinants of exactly which patients do receive transfusions remains to be defined and have been the subject of considerable debate in recent years. Concerns and doubts have emerged regarding the benefits and safety of blood transfusion, in part due to the lack of evidence of better outcomes resulting from randomized studies and in part related to the observations that transfusion may increase the risk of infection. As a result of these concerns and of several studies suggesting better or similar outcomes with a lower transfusion trigger, there has been a general tendency to decrease the transfusion threshold from the classic $10 \mathrm{~g} / \mathrm{dL}$ to lower values. In this review, we focus on some of the key studies providing insight into current transfusion practices and fueling the current debate on the ideal transfusion trigger.

KEYWORDS: Anemia. Critically patients. Transfusion. Oxygen delivery. Outcomes.

\section{INTRODUCTION}

Transfusions have been in clinical use for over 50 years and have become an indispensable part of modern medical practice, especially to allow ever increasing aggressive therapy in older, sicker, and debilitated patients. ${ }^{1}$ Approximately 14 million units of whole blood are collected and transfused each year, predominately as packed red cell units. ${ }^{2,3}$ Other components are manufactured as well, but the actual use of red cells comes dramatically close to all the blood that is collected. Yet, in spite of long-standing utilization and well-entrenched beliefs on the benefits of erythrocyte transfusion, very few well-conducted studies are available to support existing clinical practice guidelines. ${ }^{1,4,5}$ Because of emerging risks associated with transfusion, economic consequences, and a few proved benefits, new and

Heart Institute - Division of Anesthesia - Intensive Care Unit - Heart Institute INCOR, São Paulo University Medical School Hospital, São Paulo, Brazil. Email: ludhmila@terra.com.br

Received for publication on March 26, 2007

Accepted for publication on Apr 24, 2007 gathering evidence is beginning to be created to answer controversial questions about transfusion.

Since 1987 when the HIV/AIDS crisis refocused lay public attention on blood transfusion and infection risks, specific criteria for transfusion and additional data concerning risks and benefits have become objects of research. ${ }^{1-}$ ${ }^{3,6,7}$ Although advances in transfusion medicine have greatly decreased the risk of viral transmission during blood transfusion, other issues now drive the debate over transfusion practice. Such issues are now much more complex, and it is clear that the concept of blood transfusion as a risk-free procedure is no longer tenable. The debate over transfusion risks over the last decade has also led to a more critical examination of transfusion benefits. ${ }^{7}$ Starting from the 1940s, some questions still remain to be appropriately answered: a) does transfusion improve outcome? b) is anemia a marker of risk? c) which are the real benefits and risks of transfusion? d) are there well-conducted studies to guide transfusion decision making? e) is there a trigger for hemoglobin in critical patients? f) should cardiac patients be individualized? g) are there alternative methods to avoid transfusion? 
The purpose of this review is to determine whether the existing recommendations for red blood cell transfusions are adequate answers to these questions, to consider the available data, and to look for strategies to minimize loss of blood.

\section{ANEMIA IN THE CRITICALLY ILL}

Anemia is very common in critically ill patients; almost $95 \%$ of patients admitted to intensive care units (ICU) are found to have hemoglobin levels below normal by ICUday $3 .{ }^{5}$ As a consequence, critically ill patients receive large numbers of red blood cell (RBC) transfusions. Studies demonstrate that $50 \%$ of all patients admitted to the ICU and $85 \%$ who stayed for more than 1 week received at least 1 RBC unit. ${ }^{8}$

The prospective, multiple-center, observational cohort CRIT study in the United States, which included 4892 ICU patients, reported that almost two thirds of such patients had hemoglobin concentrations of $<12 \mathrm{~g} / \mathrm{dL} .{ }^{9}$ The etiology of anemia is multifactorial (Table 1).

Table 1 - Causes of anemia in the intensive care unit patient

Pre-existing chronic anemia

Acquired anemia

Hemodilution

Blood losses

- $\quad$ Surgery, trauma

Gastrointestinal bleeding

Other sources of bleeding

Blood sampling

Other procedures

Decreased red blood cell production

Decreased erythropoietin synthesis

Resistance to erythropoietin

Iron deficiency

Decreased red blood cell life span

Increased hemolysis

Nutritional deficiencies

Although primary blood loss from trauma, surgery, gastrointestinal bleeding, etc, represents a key cause of anemia in the ICU patient, hemoglobin concentrations decrease even in nonbleeding critically ill patients. ${ }^{10}$ In all likelihood, the pathogenesis of this decrease in hemoglobin concentrations in nonbleeding ICU patients is a combination of losses from phlebotomy and minor procedures, reduced red cell production, and possibly increased red cell destruction. ${ }^{11}$
Repeated blood sampling can cause significant blood loss. In the Anemia and Blood Transfusion in Critical Care Study (ABC), the average daily phlebotomy volume was $41 \mathrm{~mL} /$ day. ${ }^{8}$ An abnormal erythropoietin response to blood loss, in part related to the effects of inflammatory mediators on the production of erythropoietin and of the erythropoietin receptor ${ }^{12,13}$ and by induction of apoptosis of erythroblasts, ${ }^{14}$ also contributes to the anemia in ICU patients. ${ }^{15-17}$ Inflammatory cytokines such as tumor necrosis factor alpha, interleukin-1, and interleukin- 6 have been shown to directly inhibit erythropoietin production and red cell formation. Nutritional deficiencies, including iron deficiency, may contribute to decreased production. ${ }^{18}$ Vasodilation secondary to the inflammatory response may lead to an increased blood volume, which in turn may contribute to a decreased hematocrit in spite of a constant red cell mass. Increased red blood cell (RBC) uptake by the reticuloendothelial system due to alterations of the RBC membrane ${ }^{19}$ could also contribute to the development of anemia in critically ill patients.

The "Sepsis Occurrence in Acutely Ill Patients study (SOAP)", ${ }^{20}$ which included 3147 patients from European ICUs, reported that $33 \%$ of the patients received a blood transfusion during their stay.

\section{EFFICACY OF ALLOGENEIC RED BLOOD CELL TRANSFUSIONS AND TOLERANCE TO ANEMIA}

Blood transfusions are given with the aim of improving oxygen delivery and hence limiting tissue hypoxia and damage. However, although oxygen delivery is enhanced, a concomitant increase in tissue oxygenation or oxygen utilization is not a necessary consequence.$^{21-23}$ In addition, risks are associated with blood transfusions including transmission of microorganisms; transfusion-related immunomodulation, which may increase the risk of infections; transfusion-related acute lung injury; and human errors (wrong type and cross-match, incorrect patient identification, etc), which can cause hemolytic reactions.

In 1999, Hébert et $\mathrm{al}^{24}$ published the results of a randomized controlled study that facilitated discussion as to the real benefits of transfusion. This study compared the outcomes of critically ill patients managed with a liberal blood transfusion strategy (hemoglobin concentration kept at $>10 \mathrm{~g} / \mathrm{dL}$ as was general practice at the time) with a restrictive transfusion practice (hemoglobin concentration maintained at $>7 \mathrm{~g} / \mathrm{dL}$ ). Patients in the liberal group received a mean of 5.6 units of RBCs, compared with 2.6 units in the restrictive group $(P<.01)$. mortality rates in the ICU and hospital were lower in the restrictive group, but the differences were only significant for hospital mor- 
tality ( $22 \%$ vs. $28 \%, P=.05)$. In the subgroups of patients with lower Acute Physiology and Chronic Health Evaluation II scores $(<20)$ and younger age $(<55$ years $)$, mortality rates were notably lower in the restrictive group than the liberal group. The authors concluded that "hemoglobin concentrations should be maintained between 7.0 and 9.0 g per deciliter."

Although blood transfusions clearly carry risks, available data clearly show that anemia is associated with worse outcomes. .,9,25,26 On the other hand, data from animal experiments suggest that acute hemodilution to low hemoglobin levels is well tolerated; in healthy human volunteers, acute isovolemic reduction of blood hemoglobin concentration to $5 \mathrm{~g} / \mathrm{dL}$ yield no evidence of inadequate systemic oxygenation, ${ }^{27}$ but side effects such as arrhythmia $^{28}$ have been observed. However, although healthy individuals maintain oxygen consumption by corresponding increases in cardiac index and oxygen extraction ratio during isovolemic hemodilution, in critically ill patients, the relationship between cardiac index and oxygen extraction may be different. ${ }^{28}$ Consequently, results from studies in healthy volunteers are unlikely to be applicable to the majority of ICU patients. An acceptable hemoglobin concentration is the degree of anemia that is the best balance between the risks of red cell transfusion and the risks of low hemoglobin concentration.

Some controversial data suggest a higher risk of death for patients with anemia. Data obtained from 1958 Jehovah's Witness patients undergoing surgery, show a mortality rate of $1.3 \%$ in patients with a preoperative hemoglobin of ${ }^{3} 12$ $\mathrm{g} / \mathrm{dL}$ and $33.3 \%$ in patients with a preoperative hemoglobin $<6 \mathrm{~g} / \mathrm{dL}$. The increase in the risk of death associated with a low preoperative hemoglobin was more pronounced in patients with cardiovascular disease. ${ }^{25}$ In a retrospective study of 2083 patients who declined RBC transfusion for religious reasons, the odds of death in patients with a postoperative hemoglobin level of $<8 \mathrm{~g} / \mathrm{dL}$ increased 2.5 times for each gram decrease in hemoglobin level after adjusting for age, cardiovascular disease, and Acute Physiology and Chronic Health Evaluation II score. ${ }^{26}$ In an observational study of 4470 critically ill patients, patients with cardiac disease and hemoglobin concentrations $<9.5 \mathrm{~g} / \mathrm{dL}$ a trend toward increased mortality rate ( $55 \%$ vs. $42 \%, P=.09$ ) was observed, compared with anemic patients with noncardiovascular diseases. ${ }^{29}$ Habib et $\mathrm{al}^{30}$ noted that increased hemodilution severity during cardiopulmonary bypass was associated with worse perioperative vital organ dysfunction/morbidity and increased resource use, as well as greater short- and intermediate-term mortality.

With the ongoing debate regarding the benefits and risks of blood transfusions, it is important that each patient is assessed individually to determine his or her tolerance to anemia and need for transfusion. However, how can such patients be assessed? Clinical examination combined with background data including current diagnosis and comorbid conditions will help determine the need for transfusion. ${ }^{8}$ Hemoglobin concentration would be an easy variable and, indeed, has for years been the guiding factor for the "transfusion trigger;" however, the optimal hemoglobin concentration varies considerably from one patient to the next according to multiple factors including age, preexisting chronic diseases (especially coronary artery disease), present diagnosis, underlying cause of the anemia, and tolerance to anemia. ${ }^{8}$ Therefore, a single hemoglobin level below which all patients should be transfused, or a scale of values for specific groups of patients, is too inflexible a rule, and maybe subject to errors.

The "critical hemoglobin," that is, the hemoglobin level below which oxygen delivery is compromised, would be a more reliable trigger, but how can this be measured? Currently, we have only surrogate measures of tissue oxygenation, including mixed venous oxygen saturation, base excess, and blood lactate levels. Even if we did have an effective means of detecting tissue hypoxia, should interventions such as blood transfusions be indicated once hypoxia has already developed?

Commonly used indices of tissue hypoxemia on a whole body level are oxygen consumption $\left(\mathrm{VO}_{2}\right)$, plasma lactate concentration, mixed venous oxygen saturation $\left(\mathrm{SVO}_{2}\right)$, and mixed venous oxygen partial pressure $\left(\mathrm{PvO}_{2}\right){ }^{31}$ Regional indices include gastric tonometry derived indices- $-\mathrm{pHi}$ and $\mathrm{PCO}_{2}$ gap. When all such studies are taken into account there is little evidence that red blood cell transfusion consistently improves clinical indices of tissue hypoxia in euvolemic critically ill patients. Not even transfusion with very fresh red blood cells could be shown to improve clinical indices of tissue hypoxia in euvolemic critically ill patients. ${ }^{31}$ These data show that although clinicians frequently transfuse because they are concerned about inadequate oxygen delivery to tissues, this does not usually result in measurable improvements using currently available indices of tissue hypoxia. ${ }^{32}$

Thus we return to the hemoglobin concentration as our guide to transfusion; but at what hemoglobin level should we transfuse? The study by Hébert et $\mathrm{al}^{24}$ demonstrated that critically ill patients could be successfully managed with hemoglobin concentrations between 7 and $9 \mathrm{~g} / \mathrm{dL}$, with the possible exception of patients with acute myocardial infarcts and unstable angina. Current recommendations for the management of patients with severe sepsis support a transfusion trigger of $7 \mathrm{~g} / \mathrm{dL} .{ }^{33}$ In addition, studies in Jehovah's Witness patients have shown that survival is pos- 
sible at low hemoglobin concentrations; one case study reported survival after a decrease in hemoglobin concentration to as low as $1.8 \mathrm{~g} / \mathrm{dL}{ }^{34}$ To understand the individual tolerance to anemia we must discuss oxygen transport and delivery to tissues.

\section{OXYGEN TRANSPORT}

Oxygen delivery $\left(\mathrm{Do}_{2}\right)$ is defined as the product of cardiac output $(\mathrm{CO})$ and arterial oxygen content $\left(\mathrm{CaO}_{2}\right)$ as shown in the following formula:

$\mathrm{DO}_{2}=\mathrm{CO} \mathrm{X} \mathrm{CaO}$

where $\mathrm{Do}_{2}$ is expressed in $\mathrm{mL} / \mathrm{min}, \mathrm{CO}$ in $\mathrm{dL} / \mathrm{min}$, and $\mathrm{CaO}_{2}$ in $\mathrm{mL} / \mathrm{dL}$.

The arterial oxygen content is expressed by the following formula:

$\mathrm{CaO}_{2}=\left(\mathrm{SaO}_{2} \times 1.34 \times \mathrm{HB}\right)+\left(0.0031 \times \mathrm{PaO}_{2}\right)$

where $\mathrm{SaO}_{2}$ is the arterial oxygen saturation (\%), 1.34 is the oxygen-carrying capacity of hemoglobin $(\mathrm{mL} / \mathrm{g}),[\mathrm{Hb}]$ is the hemoglobin concentration $(\mathrm{g} / \mathrm{dL}), 0.0031$ is the solubility of oxygen in plasma at $37^{\circ} \mathrm{C}[\mathrm{mL} /(\mathrm{dL} \cdot \mathrm{mm} \mathrm{Hg})]$, and $\mathrm{PaO}_{2}$ is partial $\mathrm{O}_{2}$ pressure in $\mathrm{mm} \mathrm{Hg}$.

The ratio of oxygen consumption $\left(\mathrm{VO}_{2}\right) /\left(\mathrm{Do}_{2}\right)$ is defined as oxygen extraction ratio $\left(\mathrm{O}_{2} \mathrm{ER}\right)$. Under normal conditions, $\mathrm{O}_{2} \mathrm{ER}$ is in the range of $20 \%$ to $30 \%$ because $\mathrm{Do}_{2}$ (800 to $1200 \mathrm{~mL} / \mathrm{min}$ ) exceeds $\mathrm{Vo}_{2}(200-300 \mathrm{~mL} / \mathrm{min}) 3$ to 5 fold. Therefore, hemoglobin concentration and thus $\mathrm{Do}_{2}$ can significantly decrease without affecting $\mathrm{Vo}_{2}$, which is therefore $\mathrm{Do}_{2}$-independent. However, below a critical threshold of hemoglobin concentration $\left(\mathrm{Hb}_{\text {CRIT }}\right)$ and $\mathrm{Do}_{2 \mathrm{CRIT}}$, respectively, $\mathrm{Vo}_{2} / \mathrm{Do}_{2}$-dependency is reached. This means that below this threshold, any further decrease in $\mathrm{Do}_{2}$ or $\mathrm{Hb}$ also results in a decrease in $\mathrm{Vo}_{2}$ and in tissue hypoxia. ${ }^{35}$ The concept of critical oxygen delivery $\left(\mathrm{Do}_{2 \mathrm{CRIT}}\right)$ is important to the understanding of cellular hypoxia and shock. Tissue oxygen delivery is determined by oxygen-carrying capacity (hemoglobin concentration and the oxyhemoglobin dissociation curve) and cardiac output. Decreases in cardiac output can lead to cardiogenic shock if the cardiac output falls low enough that $\mathrm{Do}_{2 \mathrm{CRIT}}$ or supplyindependent oxygen delivery to tissues is not met.

This leads to an important question: which physiological mechanisms compensate for a decrease in hemoglobin concentration in anemia in order to maintain $\mathrm{Do}_{2}$ above $\mathrm{Do}_{2 \text { CRIT }}$ ?

Although the extent of compensatory mechanisms to acute anemia may vary depending on factors such as the patient's underlying diseases, the underlying basic principles remain the same. The basic compensatory mechanisms to anemia are central, regional, and microcirculatory changes in blood flow and a shift of the oxyhemoglobin dissociation curve to the right (a decrease in hemoglobin affinity for oxygen). ${ }^{36}$ Acute normovolemic anemia results in an increase in Cardiac Output ${ }^{27}$ The decrease in blood viscosity leads to a facilitated venous return with an increased preload and a decreased afterload. ${ }^{37}$ In addition, sympathetic stimulation increases inotropy, contributing thereby to further increase the output ${ }^{37}$ If this is maintained or allowed to increase in response to dilutional anemia and if the cardiac preload is maintained, anemia is surprisingly well tolerated. Compensatory mechanisms for progressive euvolemic anemia include not only an increase in cardiac output (increased left ventricular emptying and tachycardia) but also a change in the oxygen extraction ratio from the erythrocyte itself. Prospective randomized trials ${ }^{42-44}$ and an additional meta-analyse ${ }^{38-44}$ have failed to confirm the benefit of achieving supranormal values of oxygen delivery and oxygen use. They have also raised the possibility that this strategy may result in worse clinical outcomes and increased mortality. This debate aside, improvement in oxygen delivery is often a clinical goal in the treatment of the critically ill.

Finally, microcirculatory changes take place leading to a recruitment of capillaries and homogeneous blood flow through the capillary bed, which in turn enables increased oxygen extraction. ${ }^{36}$

Anemia results in an increase of RBC 2,3-diphosphoglycerate concentration. This results in a shift of the oxyhemoglobin dissociation curve to the right, favoring oxygen release. ${ }^{35,38}$

The patient's individual tolerance to anemia is one of the most important factors regarding decisions on transfusions. Thus, it is mandatory to assess the capacity of each patient to compensate for an acute decrease in hemoglobin concentration. The greatest challenge in transfusional practice today is to determine on an individual basis the tolerance to anemia and mechanisms of adaptation.

\section{STUDIES EVALUATING THE OUTCOME OF RED BLOOD CELL TRANSFUSIONS}

Transfusions have been in clinical use for over 50 years and have become an indispensable part of modern medical practice, especially to allow for more aggressive therapy in older, sicker, and debilitated patients. Yet, despite longstanding utilization and well-entrenched beliefs regarding the benefits of erythrocyte transfusion, very few well-conducted studies are available to support existing clinical 
practice guidelines. ${ }^{45}$ In 1988 , the National Institutes of Health recommended that the only justification for the transfusion of red blood cells is the need to augment oxygen transport to the tissues. ${ }^{46}$ Unfortunately, in 2007, it is still not possible to determine precisely, in every day clinical practice, when oxygen transport does not meet oxygen requirements. The lack of well-conducted studies on the benefits of transfusion and our inability to adequately monitor tissue oxygenation at the bedside have forced clinicians to rely on "expert opinion" for guidance. We will attempt to determine if the existing evidence for RBC transfusions should be re-examined, in light of the few human studies which are currently available.

One of the first descriptive studies of ICU transfusion practice was published by Corwin et al in $1995 .{ }^{47}$ In this retrospective chart review of 142 ICU patients who had a length of stay greater than 1 week, $85 \%$ had received blood transfusions. They found that only $35 \%$ of the transfusion events were for acute blood loss, while $29 \%$ had no identifiable trigger. With the exception of the cases in which a low hematocrit was the trigger, the average pretransfusion hematocrit was $27 \%$.

Further insight into ICU transfusion practices occurred in 1998 when Hébert et al published the results of a survey of Canadian critical care physicians ${ }^{48}$ Their data collected from the responses of 193 physicians showed a wide degree of variability in transfusion practices, with most of the transfusion thresholds ranging from 8.0 to $10.0 \mathrm{~g} / \mathrm{dL}$ hemoglobin. Overall, $35 \%$ of physicians selected a transfusion threshold of $9.0 \mathrm{~g} / \mathrm{dL}$, and $40 \%$ selected a threshold of $10.0 \mathrm{~g} / \mathrm{dL}$. Once they decided to transfuse, more than $90 \%$ of physicians administered 2 units of RBC.

In all of transfusion medicine, there has been only 1 large randomized trial to date. This is the Transfusion Requirements in Critical Care (TRICC) study by Hébert and colleagues. ${ }^{24}$ The TRICC study enrolled 838 patients and was the largest trial adequately powered to evaluate the impact of different transfusion strategies on mortality and morbidity. It has been named the single most important report in the history of transfusion. It was published in 1998 and was a cooperative study performed at 25 different Canadian academic institutions. The patient group studied was a cohort of medical intensive care patients. Hébert and the Canadian Clinical Trials Group conducted a randomized controlled trial of patients in ICUs who were transfused at either 7.0 $\mathrm{g} / \mathrm{dL}$ or $10.0 \mathrm{~g} / \mathrm{dL} .{ }^{24}$ Using the primary endpoint of 30-day mortality from all causes and several other secondary endpoints, the authors showed that using the lower transfusion threshold was at least as safe as the higher value. In several subgroups, such as patients younger than 55 years and patients with lower severity scores (Acute Physiology and Chronic Health Evaluation [APACHE] II less than 20), they found a statistically significant mortality benefit in the lower transfusion trigger group. Other mortality time points such as in-hospital mortality and 60-day mortality also showed a statistically significant benefit to the lower threshold. In addition to these clinical outcomes data, the blood use was dramatically different in the two groups. The low transfusion threshold group received about half as many units of blood (average of 2.6 units versus 5.6 units per patient). The TRICC study ${ }^{24}$ documented an overall nonsignificant trend toward decreased 30-day mortality ( $18.7 \%$ versus $23.3 \%, P=.11$ ) and significant decreases in mortality among patients who were less acutely ill $(8.7 \%$ versus $16.1 \%, P$ $=.03$ ) in the group treated using a hemoglobin trigger of 7 $\mathrm{g} / \mathrm{dL}$ compared with a more liberally transfused group that received 54\% more red cell transfusions. The investigators also noted that the 30-day mortality rates were significantly lower with the restrictive strategy among patient who were less acutely ill (APACHE II scores $<20$ ) and among patients who were less than 55 years of age.

The findings of the TRICC study found no advantage to transfusion (Table 2). ${ }^{24}$ Overall mortality did show just how ill the group studied had been. The in-house, 30-day mortality rate did show that patients who had transfusions at the lower trigger had a statistically lower mortality rate. The overall myocardial infarction (MI) rate was low, and the rate was statistically lower in those patients who were allowed to become profoundly anemic and not have a transfusion. The occurrence of ARDS and pulmonary edema were also statistically significant and strikingly lower in the group that received less blood. Of interest, there was no overall difference in infection rate in the two groups.

Two large multicenter studies have been performed in the years since the publication of the randomized controlled trial of Hébert et al that have furthered understanding of current transfusion practice. The first study was pub-

Table 2 - Results from the TRICC study by Hébert and colleagues $^{24}$

\begin{tabular}{lccc}
\hline Category & Restrictive & Liberal & $P$ value \\
\hline All patients & 18.7 & 23.3 & .10 \\
APACHE II & 8.7 & 16.1 & .03 \\
Age < 55 yr & 5.7 & 13.0 & .02 \\
Cardiac diagnosis & 20.5 & 22.9 & .69 \\
Death in the hospital & 22.2 & 28.1 & .05 \\
MI & 0.7 & 2.9 & .02 \\
Pulmonary edema & 5.3 & 10.7 & $<.01$ \\
Angina & 1.2 & 2.1 & .28 \\
ARDS & 7.7 & 11.4 & .06 \\
Infectious & 10.0 & 11.4 & .38 \\
\hline
\end{tabular}

Nowhere in these data did patients who had more transfusions do better. There were large differences in the rate of MI and in pulmonary dysfunctions. $\mathrm{MI}=$ myocardial infarction ARDS = acute respiratory distress syndrome 
lished in 2002 by Vincent et al and titled the ABC study (Anemia and Blood Transfusion in Critically Ill Patients). ${ }^{8}$ The stated objectives of this study were to define the incidence of anemia in critically ill patients, describe transfusion practices, and explore possible risks and benefits associated with transfusion. Data were collected at 146 ICUs in 15 countries throughout Europe and encompassed 3534 patients. Most of the ICUs (71\%) had mixed medical and surgical patients. First, the sub-study on phlebotomy showed that blood withdrawal was considerable, averaging $41 \mathrm{~mL}$ per day. The rest of the data gives a very good picture of the average transfusion requirements and practices in these ICUs. Overall, the transfusion rate for the whole 28-day period (including post-ICU time) was $41 \%$ for 3534 patients included. The average hemoglobin level was 11.3 at admission, and the average pretransfusion hemoglobin was $8.4 \mathrm{~g} / \mathrm{dL}$. There was no difference in the average pretransfusion hemoglobin for patients who were thought to be actively bleeding $(8.4 \mathrm{~g} / \mathrm{dL})$ and those who were not $(8.5 \mathrm{~g} / \mathrm{dL})$. This is surprising, in that physicians are generally more likely to transfuse a patient at a higher hemoglobin level if they know of active bleeding. One factor that may explain this was that patients transfused for the indication of coronary artery disease alone had a higher than average transfusion threshold of $8.7 \mathrm{~g} / \mathrm{dL}$.

The data showed a positive correlation between receiving any blood transfusions and 28-day mortality. The mortality risk increased with the number of units transfused. The authors then divided the patients by organ dysfunction scores and showed an increase in mortality in the transfused versus nontransfused patients in all but the most severely ill patients. Finally, a logistic regression model was used to generate propensity scores for two groups of matched patients in an effort to adjust for characteristics other than transfusion. The data, which compared 516 transfused versus 516 nontransfused patients matched for patient characteristics, showed a significantly higher mortality in transfused patients $(22.7 \%$ versus $17.1 \% ; P=0.02) 8$.

A multicenter study called the CRIT Study that sought to quantify transfusional practices of ICUs in the United States and describe associated clinical outcomes and complications has been published. ${ }^{9}$ Patients who were admitted to any medical, surgical, or mixed ICU were enrolled and followed for 30 days or until death or discharge from the hospital. The study took place at 284 ICUs in 213 hospitals. The ICUs were $31 \%$ medical, $29 \%$ surgical, and $40 \%$ mixed. Residents were present in $76 \%$ of the ICUs, and $71 \%$ were open ICUs. The study included 4892 patients with an average age of 60 years. Overall, ICU and in-hospital mortality rates were $13 \%$ and $18 \%$, respectively. Similarly to what was seen in previous studies, the average hemoglobin declined steadily over time. Overall, $44.1 \%$ of patients were transfused while in the ICU, and $48.2 \%$ were transfused during the total 30 -day observation period. ${ }^{9}$ The average pretransfusion hemoglobin was $8.6 \mathrm{~g} / \mathrm{dL}$. Subgroup analysis showed a higher threshold for surgical $(8.8 \mathrm{~g} / \mathrm{dL})$ than for medical $(8.2 \mathrm{~g} / \mathrm{dL})$ patients. All patients had severity scores calculated (APACHE II and sequential organ failure assessment [SOFA]), and there was a positive correlation between severity of illness and the number of units transfused.

As in previous studies, the authors looked for an association between number of units transfused and clinical outcomes. Multivariate analysis showed that the number of RBC units transfused was associated with increased ICU and hospital length of stay compared with nontransfused patients. Furthermore, RBC transfusion also was independently associated with higher mortality rates. As in the $\mathrm{ABC}$ trial, investigators used adjusted case matching analysis to look for any additional mortality risk conveyed by the transfusion of RBCs independently. Investigators matched 1059 transfused patients to 1059 nontransfused patients and adjusted for the propensity for receiving a blood transfusion. Blood transfusion remained significantly associated with an increased risk for death (adjusted mortality ratio, 1.65; 95\% CI, 1.35-2.03; log-rank $P<.001$ ).

Unfortunately as evidenced by a recent systematic review, there is a paucity of clinical trials comparing restrictive to liberal transfusion studies to examine the efficacy of RBC transfusion. Carson et $\mathrm{al}^{49}$ were able to identify only 10 randomized clinical trials of adequate methodological quality in which different RBC transfusion triggers were evaluated. Included were a total of 1780 surgery, trauma, and ICU patients enrolled in trials conducted over the past 40 years. The trigger evaluated in these trials varied between 7 and $10 \mathrm{~g} / \mathrm{dL}$. Data on mortality or hospital length of stay was only available in 6 of these trials. Conservative transfusion triggers were not associated with an increase in mortality; on average, mortality was one-fifth lower $(R R 0.80$; 95\% CI 0.63-1.02) with conservative compared with liberal transfusion triggers. Likewise, cardiac morbidity and length of hospital stay did not appear to be adversely affected by the lower use of RBC transfusions. There was insufficient data on potentially relevant clinical outcomes such as stroke, thromboembolism, multiorgan failure, delirium, infection or delayed wound healing to perform any pooled analysis. Carson and colleagues ${ }^{49}$ stated there were insufficient data to address the full range of risks and benefits associated with different transfusion thresholds, particularly in patients with coexisting disease. They also noted that their meta-analysis was dominated by a single trial: the TRICC trial, ${ }^{8}$ which enrolled 838 patients and 
was the only individual trial identified that was adequately powered to evaluate the impact of different transfusion strategies on mortality and morbidity.

Recently, a study published by Rivers et $\mathrm{a}^{50}$ documented that the use of early goal-directed care based on hemodynamic variables and a mixed central venous saturation decreased mortality from $46.5 \%$ in the control group to $30.5 \%$ in the goal-directed therapy group $(P=.009)$. The goal-directed therapy group received more RBC transfusions in the first 6 hours of care and presented higher survival rates.

The recent SOAP study enrolled 3,147 patients of whom $33 \%$ received an RBC transfusion. Patients receiving transfusions were older and generally sicker. ${ }^{20}$ Therefore, it is not surprising that mortality rates were higher in transfused patients. However, after propensity score matching, mortality rates were the same in transfused and in nontransfused patients, with a tendency towards lower survival in nontransfused patients. Thus the SOAP study contrasts with the CRIT and ABC studies; this could be due to implementation of deleukocytation in Europe. ${ }^{20}$

Current evidence from studies of the influence of allogeneic blood transfusion on efficacy and clinical outcome is seriously hampered by the absence of a significant number of adequately powered randomized clinical trials. However, one point should be considered. Most studies suggest that hemoglobin levels of 7-9 g/dL are well tolerated by most critically ill patients and that a transfusion threshold of $7 \mathrm{~g} / \mathrm{dL}$ is appropriate.

\section{TRANSFUSION IN CARDIAC SURGERY}

Blood conservation strategies in the cardiac surgery population are of interest because of the volume of blood product support provided to these patients and the complexity of the bleeding management issues confronting the patient care team..$^{51-53}$ The etiology of excessive bleeding after cardiac surgery is multifactorial and related to surgical complexity, the use of anticoagulants/heparin during surgery, the coexistence of multiple hemostatic aberrations produced during cardiopulmonary bypass, damage to blood vessel walls during the operation, and the quality of the surrounding tissue following the procedure. Acquired defects in hemostasis may include coagulopathy from hypothermia, hemodilution, or abnormal fibrinolysis. ${ }^{51}$ Abnormal platelet contribution to hemostasis also occurs, whether from prior antiplatelet agents, platelet activation from the bypass circuit, platelet consumption, or platelet loss. ${ }^{52}$ Despite complete heparin reversal and the use of antifibrinolytic agents, excessive bleeding still occurs. Abnormal or excessive bleeding after cardiac surgery occurs in $3 \%$ to $11 \%$ of patients; ${ }^{53,54}$ it requires surgical re-exploration in approximately $5 \%$ of patients, ${ }^{54}$ in whom inadequate surgical hemostasis is identified in up to $50 \%$ to $60 \%$ of them, ${ }^{55}$ and increases the risk of mortality 3 to 4 times. ${ }^{56}$ Excessive bleeding has been associated with CPB duration exceeding 2.5 hours, repeat or combined cardiac procedures, renal dysfunction, older age, smaller body surface area, and the use of anticoagulants or antiplatelet agents. $^{51}$

Extensive transfusion of allogeneic blood products has been associated with many adverse events, including bacterial infection, viral transmission, transfusion-related acute lung injury, volume overload, and increased mortality. ${ }^{53,57,58}$ In spite of some published algorithms and guidelines, large variability in transfusional practices still persists. ${ }^{59.60}$

In summary, it is clear that excessive bleeding from multifactorial causes that occurs after cardiac surgery creates significant medical and financial burdens. Several studies suggest that adhering to transfusion algorithms, especially in conjunction with concomitant hemostasis monitoring, may (1) decrease the number of transfusions administered, (2) decrease the volume of blood lost, and (3) decrease the rate of re-exploration for bleeding. ${ }^{51} \mathrm{It}$ is also evident from these series, however, that optimal hemostasis monitoring and applicability/predictive value to in vivo hemostasis can be further refined and awaits additional clinical investigation.

\section{TRANSFUSION IN HEART DISEASE}

Considering the risks and the lack of clear evidence regarding the benefits of allogeneic blood, ${ }^{61}$ the American Society of Anesthesiologists established the Task Force on Blood Component Therapy to develop evidence-based indications for the transfusion of red blood cells. ${ }^{62}$ They concluded that "red blood cell transfusions should not be dictated by a single hemoglobin 'trigger' but instead should be based on the patient's risk of developing complications due to inadequate oxygenation." In addition, they noted that a blood transfusion generally would be indicated, but would not be mandatory, ${ }^{62,63}$ at hemoglobin levels less than $6.0 \mathrm{~g} /$ $\mathrm{dL}$, but very rarely would a blood transfusion be indicated at hemoglobin levels greater than $10.0 \mathrm{~g} / \mathrm{dL}$. The evidence available at present does not support higher transfusion thresholds $(9-10 \mathrm{~g} / \mathrm{dL})$ in patients with cardiovascular diseases. ${ }^{1}$ However, this group of patients still presents the highest rates of transfusion. Why continue to recommend high hemoglobin concentration thresholds in patients with cardiovascular disease?

Patients with coexisting cardiac diseases may have a particular risk of developing inadequate oxygenation at low 
hemoglobin levels, either in the form of myocardial ischemia (in patients with coronary artery disease) or in the form of an inadequate cardiac output (in patients with limited cardiac contractile functions).

Regarding the patient's tolerance to anemia, patients with cardiovascular disease could be at particular risk. In coronary artery disease, an adequate increase in the coronary blood flow in response to a decrease in hemoglobin concentration is not possible, and myocardial ischemia may develop. In a retrospective cohort study in 1958, patients who declined blood transfusions for religious reasons corroborated this hypothesis. ${ }^{25}$ It was found that below a preoperative hemoglobin level of $10-11 \mathrm{~g} / \mathrm{dL}$, mortality increased in patients with and without cardiovascular disease, but more so in the cardiovascular disease group. Similarly, in a subgroup analysis of an observational study evaluating the effect of anemia and blood transfusion strategies on mortality, Hebert et al found an association between anemia and risk of death in critically ill patients with cardiac disease. ${ }^{29}$ Increasing their hemoglobin values resulted in improved survival in this subgroup of patients. In patients with cardiovascular disease, improved outcome with a liberal transfusion trigger is supported by retrospective studies. Recently, the retrospective study by $\mathrm{Wu}$ et al ${ }^{64}$ attempted to determine the benefits of red blood cell transfusions in 78,974 elderly patients with acute myocardial infarction and various degrees of anemia. The study suffered from several limitations including its retrospective nature; the lack of a temporal relationship between hematocrit, transfusions, and mortality; and the borderline statistical significance of the results. In fact, mortality was increased when the initial hematocrit was below $24 \%$ in nontransfused patients or above $36.1 \%$ in transfused patients. The authors conclude that their data suggest that elderly patients with an acute myocardial infarction will benefit from transfusions whenever the hematocrit on admission is $30 \%$ or lower. The accompanying editorial concluded": "on the basis of the evidence presented by $\mathrm{Wu}$ et al, we recommend that hematocrit levels should be maintained above $33 \%$ in patients with acute myocardial infarction." We find this conclusion incorrect, especially based in fact that the hematocrit trigger of $33 \%$ was not truly supported by Wu's data. ${ }^{64}$

When we look to the evidence coming from randomized controlled trials, there are a few available data to clarify the topic. Published studies show no relation between higher levels of hemoglobin in cardiac patients and lower mortality. A subgroup analysis of the TRICC trial showed no differences in mortality rate between the restrictive and the liberal transfusion strategies in patients with CVD. ${ }^{24}$ Although the authors claim to be aware of the possible limi- tations of this subgroup analysis, they suggested that a transfusion trigger of $7 \mathrm{~g} / \mathrm{dL}$ would be safe in critically patients with CVD diseases. More recently, Rao et al ${ }^{65}$ examined detailed prospectively collected data for 24,112 patients who were enrolled in 3 international randomized trials in patients with acute coronary syndromes. Of these patients 2,401 (10\%) received at least 1 transfusion during hospitalization. Using complex statistical approaches, which included adjustments for comorbidities and time from admission, authors found an increased risk for 30-day mortality among patients who received a transfusion. When the authors explored the importance of the lowest hemoglobin value in the patients, there was no demonstrable benefit from transfusion on mortality probability in their statistical model at hematocrit values between $20 \%$ to $25 \%$, while at values above $30 \%$ transfusion was associated with a higher probability for death. These data are difficult to interpret and illustrate the limitations of cohort studies for addressing questions concerning anemia, blood transfusions, and outcomes in clinical conditions in which many factors influence mortality.

There is an urgent need for prospective randomized trials of transfusion strategy for patients with ischemic heart disease, particularly as up to $28 \%$ of general intensive care populations may have cardiac disease at admission. ${ }^{31}$

The question of when to transfuse an individual patient with a coexisting cardiac disease thus remains unanswered except for the notion that at hemoglobin levels of less than $6.0 \mathrm{~g} / \mathrm{dL}$ blood transfusions may be indicated in most patients, in particular in patients with coexisting cardiac diseases. ${ }^{66,67}$ Because it remains impossible to determine the magic hemoglobin number at which a transfusion would be generally indicated, guidelines published in $2006^{62}$ by the American Society of Anesthesiologists should be followed, stating that "(the decision for) red blood cell transfusions should be based on the patient's risk of developing complications of inadequate oxygenation" even for patients with coexisting cardiovascular disease. The question which then follows is "what are the signs of a beginning inadequate oxygenation in patients with coexisting cardiac diseases?"

Inadequate oxygenation may become manifest locally in the form of myocardial ischemia or globally in the form of a general hemodynamic instability with a tendency to hypotension and tachycardia despite normovolemia. Myocardial ischemia may be detected by continuous 5-lead electrocardiogram monitoring, ideally with automatic STsegment analysis ${ }^{68,69}$ and by (transesophageal) echocardiography. ${ }^{70}$ Therefore, new ST-segment depressions greater than $0.1 \mathrm{mV}$ or new ST-segment elevations greater than $0.2 \mathrm{mV}$ during more than 1 minute are generally re- 
garded as markers of myocardial ischemia. During progressive hemodilution, one mostly observes ST-segment depression, ${ }^{69}$ suggesting subendocardial ischemia. Such anemiarelated ischemia is reversible by decreasing the heart rate, if elevated, and by minimal transfusion to increase the hemoglobin by 1 to $2 \mathrm{~g} / \mathrm{dL} .{ }^{71}$ Also, new wall motion abnormalities clinically detected by trans-esophageal echocardiography (and experimentally by sonomicrometry) are suggestive of myocardial ischemia and can be treated by an increase in the hemoglobin of only 1 to $2 \mathrm{~g} / \mathrm{dL}^{71}$

Early signs of inadequate circulation generally comprise hemodynamic instability characterized by a relative tachycardia and hypotension, ${ }^{6}$ an oxygen extraction rate of greater than $50 \%,{ }^{66,67}$ a low mixed-venous oxygen partial pressure $\left(\mathrm{PvO}_{2}\right)$, or a decrease in oxygen consumption. ${ }^{66,67}$ In a position report from the College of American Pathologists, an oxygen extraction rate of greater than $50 \%$, a $\mathrm{PvO}_{2}$ less than $25 \mathrm{~mm} \mathrm{Hg}$ (less than $3.3 \mathrm{kPa}$ ), and a reduction in oxygen consumption to less than $50 \%$ of baseline are described as threshold values above which a blood transfusion would be indicated. ${ }^{66}$ An oxygen extraction of greater than $50 \%$ has been found to indicate exhaustion of compensatory mechanism in several studies ${ }^{72,73}$ and thus represents a clear indication for transfusion. In contrast, a threshold of $25 \mathrm{~mm} \mathrm{Hg}$ for $\mathrm{PvO}_{2}$ appears too low, because in the studies by Moss et al, the $\mathrm{PvO}_{2}$ decreased below the threshold of $25 \mathrm{~mm} \mathrm{Hg}$ only after circulatory collapse. ${ }^{72}$ A decrease in oxygen consumption greater than $50 \%$ at normovolemia is certainly an indication for transfusion; however, such a large reduction is usually observed only after hemodynamic collapse. ${ }^{73}$ Indeed, oxygen consumption decreases very late (i.e., at very low hemoglobin levels during progressive normovolemic hemodilution ), when oxygen extraction has already increased and $\mathrm{PvO}_{2}$ decreased. ${ }^{73}$ In some recent experimental studies, acute normovolemic hemodilution was well tolerated, which corroborates tolerance to anemia. ${ }^{74-76}$ Fantoni DT et $\mathrm{al}^{74}$ showed in a study with $18 \mathrm{dogs}$ that the hemodynamic response to acute normovolemic hemodilution was characterized by improvement of the cardiac index, independent of the evaluated anesthetic agent. Otsuki DA et $\mathrm{a}^{75}$ published an experimental study with pigs submitted to normovolemic hemodilution. In this model, the acute normovolemic hemodilution promoted a decrease in $\mathrm{SVO}_{2}$ and an increase in cardiac output values. Similar results were demonstrated by the same group ${ }^{76}$ in a study that compared tolerance to oxygen privation during acute normovolemic hemodilution with different fluids. Perin D et al, in a recent paper, confirmed the findings that global and regional stability were maintained after moderate and severe hemodilution. ${ }^{77}$ However, this work showed that severe hemodilution was re- lated to increased intestinal-arterial $\mathrm{PCO}_{2}$, suggesting that monitoring gastric mucosal $\mathrm{CO}_{2}$ may be useful during major surgery or following trauma.

In patients with coexisting cardiac diseases, the principles of allogeneic blood transfusion are not basically different than those which apply to healthy patients and are also largely based on early signs of impaired oxygenation to specific organs or to the entire organism. In this scenario, impaired oxygenation may be reached at higher hemoglobin values than in healthy patients; in addition, many local logistic factors must be considered when establishing transfusion guidelines. Clinicians should regularly reassess the likely myocardial oxygen supply/demand balance of their patients and modify their transfusion decisions based on this information. Considering the response to anemia on an individual, case by case basis, is more rational than establishing the same trigger for different patients with distinct comorbidities.

\section{TRANSFUSION IN SEPTIC PATIENTS}

Over the last two decades, there has been much interest in the concept of maximizing oxygen delivery and oxygen consumption in critically ill patients. This approach was initially suggested as a result of studies by Shoemaker et al, which suggested that supranormal levels of oxygen delivery and oxygen usage in critically ill surgical patients were associated with improved clinical outcomes..$^{38-80}$ However, subsequent prospective randomized trials ${ }^{81,82}$ and an additional meta-analysis ${ }^{83}$ have failed to confirm the benefit of achieving supranormal values of oxygen delivery and oxygen use, raising the possibility that this strategy may result in worse clinical outcomes and increased mortality.

In patients with sepsis, RBC transfusion has been commonly used over the last two decades as a means to augment systemic oxygen delivery. However, clinical studies have not consistently demonstrated that this therapeutic maneuver is accompanied by an increase in oxygen use at either the whole-body level or at the level of the individual organs. Although several clinical studies have evaluated hemodynamic and oxygen transport parameters before and after RBC transfusion in critically ill patients, few studies have demonstrated a significant improvement in these variables after RBC transfusion.

An early study by Shah et al in $1982^{84}$ evaluated the impact of RBC transfusion on hemodynamics and oxygen transport in 8 critically ill trauma patients. Following transfusion of 1 unit of packed RBC (mean hemoglobin increase from $9.2 \mathrm{~g} / \mathrm{dL} \pm 0.3 \mathrm{~g} / \mathrm{dL}$ to $10.1 \mathrm{~g} / \mathrm{dL} \pm 0.3 \mathrm{~g} / \mathrm{dL}$ ), there were no changes in oxygen delivery, oxygen consumption, or mixed venous oxygen content. Both cardiac index and 
P50 significantly decreased following transfusion of 2 units of RBCs. Administration of RBCs thus failed to increase oxygen consumption in these trauma patients, in spite of an increase in oxygen content.

Similarly, Kahn et al in $1986^{85}$ showed that in critically ill patients, hemodynamic variables were not altered significantly by RBC transfusion; however, 2,3 DPG concentrations decreased significantly. More recently, the role of blood transfusion as a means toward improving oxygen transport was evaluated in 19 critically ill patients with sepsis syndrome. ${ }^{86}$ Oxygen uptake failed to increase in septic patients with transfusion, despite a significant increase in hemoglobin.

Treatment recommendations for pediatric patients presenting with septic shock have advocated increasing oxygen consumption $\left(\mathrm{VO}_{2}\right)$. Mink et $\mathrm{al}^{87}$ prospectively examined the effect on $\mathrm{VO}_{2}$ of improving oxygen delivery $\left(\mathrm{DO}_{2}\right)$ by increasing oxygen content with RBC transfusion in 8 hemodynamically stable septic shock patients. Transfusion significantly increased hemoglobin and hematocrit from $10.2 \mathrm{~g} / \mathrm{dL} \pm 0.8 \mathrm{~g} / \mathrm{dL}$ and $30 \% \pm 2 \%$ to $13.2 \mathrm{~g} / \mathrm{dL} \pm 1.4 \mathrm{~g} /$ $\mathrm{dL}$ and $39 \% \pm 4 \%$, respectively (mean $\pm \mathrm{SD}$ ). Although $\mathrm{DO}_{2}$ significantly increased after $\mathrm{RBC}$ transfusion, $\mathrm{VO}_{2}$ did not change significantly. Therefore, in pediatric septic shock patients, increasing oxygen content by blood transfusion did not increase $\mathrm{VO}_{2}$.

Similar findings have been demonstrated in adult patients with shock. Dietrich et $\mathrm{al}^{88}$ examined the cardiovascular and metabolic response to RBCs in patients with circulatory shock after volume resuscitation. Although $\mathrm{DO}_{2}$ was increased by $28 \%$ with RBCs, neither pulmonary artery wedge pressure, cardiac index, $\mathrm{VO}_{2}$, nor lactate was changed by augmentation of red cell mass. An increase was observed in myocardial work indices and in the MAP $\times \mathrm{HR}$ product. No changes were identified when subgroups were analyzed based on diagnosis, pretransfusion $\mathrm{Hgb}$, lactate, or $\mathrm{VO}_{2}$ levels.

Lorente et $\mathrm{al}^{89}$ performed a prospective, randomized, interventional cross-over study to investigate whether increasing $\mathrm{DO}_{2}$ by increasing hematocrit results in increases in $\mathrm{VO}_{2}$ in septic patients. A sample of 16 consecutive patients admitted to the ICU who were diagnosed as having severe sepsis by defined criteria and who had a hemoglobin concentration of less than $10 \mathrm{~g} / \mathrm{dL}$ were enrolled. Patients received, in random order, an infusion of dobutamine (10 $\grave{\mathrm{g}} / \mathrm{kg}$ per minute) and a blood transfusion $(800 \mathrm{~mL}$ of packed RBCs in 90 minutes). Changes in $\mathrm{DO}_{2}$ and $\mathrm{VO}_{2}$ induced by each intervention were measured. Dobutamine significantly increased $\mathrm{DO}_{2}(48.5 \% \pm 6.9 \% ; P=.0001)$ and $\mathrm{VO}_{2}(21.7 \% \pm 3.3 \% ; P=.0001)$. Blood transfusion increased $\mathrm{DO}_{2}(21.4 \% \pm 4.3 \% ; P=.005)$, but $\mathrm{VO}_{2}$ did not change significantly $(2.2 \% \pm 4.1 \%)$. Correlation coefficients for the percent changes of $\mathrm{DO}_{2}$ and $\mathrm{VO}_{2}\left(r^{2}=0.67\right.$, $P=.001$ for dobutamine; and $r^{2}=21, P=.07$ for blood transfusion) were significantly different for each treatment $(P=.0001)$. The authors concluded that in patients with an abnormal $\mathrm{DO}_{2}$-dependent $\mathrm{VO}_{2}$, as shown by increases in $\mathrm{VO}_{2}$ brought about by an infusion of dobutamine, blood transfusion did not increase $\mathrm{VO}_{2}$ significantly, despite significant changes in $\mathrm{DO}_{2}$.

A recent study by Fernandes et $\mathrm{al}^{90}$ evaluated hemodynamics and oxygen usage induced by hemoglobin infusion in critically ill septic patients. Hemodynamic data, gastric tonometry, and calorimetry were obtained before and immediately after RBC transfusion or $5 \%$ albumin infusion. This study documented that an increase in hemoglobin did not improve global or regional oxygen use in anemic septic patients. Furthermore, RBC transfusion may hamper right ventricular ejection by increasing the pulmonary vascular resistance index.

Recently, a study published by Rivers et $\mathrm{al}^{50}$ documented that the use of early goal-directed care based on hemodynamic variables and a mixed central venous saturation decreased mortality from $46.5 \%$ in the control group to $30.5 \%$ in the goal-directed therapy group $(P=.009)$ in patients identified in the first 6 hours of septic shock. As one of the many interventions in patients with early septic shock, hematocrit concentrations were increased beyond $30 \%$ if the central venous saturations fell below $70 \%$ after fluid reposition. As a consequence of goal-directed therapy, $64 \%$ of patients when compared with $18.5 \%$ of the control group received RBC transfusions in the first 6 hours of care $(P<.0001)$. However, given the complexity of care provided in the early goal-directed therapy trial, it is unclear how much benefit was derived from a higher transfusion trigger when compared with other interventions within the algorithm, which included fluid challenges, blood transfusion, and dobutamine infusion. ${ }^{50}$

In patients with sepsis and other shock states, RBC transfusion is commonly used to increase oxygen transport. The expected benefit from RBC transfusion is to immediately improve oxygen delivery and thus prevent cellular injury. The question regarding whether RBC transfusion improves regional microcirculation is important, since the goal of resuscitation is to improve organ perfusion and to prevent organ failure. Other studies have failed to demonstrate benefits of transfusion in septic patients. ${ }^{91-95}$

Considering the evidence from above cited studies, septic patients do not benefit from a higher hemoglobin level. The benefits of transfusion are questionable, and the risks are known in this population. Consequently, the Surviving Sepsis Campaign recommends that septic patients should 
be managed with a conservative strategy, tolerating hemoglobin levels around $7 \mathrm{~g} / \mathrm{dL} .^{33}$

\section{THE STORED BLOOD CELL}

The delivery of oxygen to tissues is the primary function of the erythrocyte. The aim of transfusion of banked red cells must be to improve tissue oxygen delivery (not oxygen carrying capacity). Other rationales for transfusion (e.g., volume expansion, support of blood pressure, and wound healing) have been promoted; however, all contemporary guidelines specifically are couched in terms of oxygen availability and delivery.

Inside the red cell a stable concentration (20-25 ìmol) of 2,3 diphosphoglycerate (2,3 DPG) is found which regulates the oxyhemoglobin dissociation curve and right-shifts the curve. With normal 2,3 DPG, the $\mathrm{P}_{50}$ or partial pressure of oxygen at which hemoglobin is $50 \%$ saturated is approximately $26 \mathrm{~mm} \mathrm{Hg}{ }^{96-98}$ Other metabolic byproducts have dramatic effects on the oxyhemoglobin dissociation curve as well. Hydrogen ion drives the curve to the right, increasing the release of oxygen as does carbon dioxide. Acidosis, therefore, increases the movement of oxygen out of hemoglobin. Under normal conditions, because of the oxyhemoglobin dissociation curve, it is possible for erythrocytes to unload a maximum $26 \%$ of their total oxygen load. For erythrocytes stored as banked blood, the maximum release of oxygen is considerably less (probably about $6 \%$ or less). The $\mathrm{P}_{50}$ of stored blood depends on how long it has been stored and the intracellular 2,3 DPG. The $\mathrm{P}_{50}$ of stored blood at 28 days is about 6 to $11 \mathrm{~mm} \mathrm{Hg}{ }^{97,99}$

Of interest, the $\mathrm{P}_{50}$ of myoglobin, a target for oxygen delivery by the red cell, is $5 \mathrm{~mm} \mathrm{Hg} .{ }^{97,99}$

Stored red cells not only exhibit a decrease in intracellular 2,3 DPG that leads to decreased oxygen release, but as they age in storage they undergo a number of other cellular changes. Biochemical, hormonal, inflammatory, and cellular structural changes all occur. Red cells change from their normal biconcave discoid shape to a globular swollen (spherocyte), or to a spiculated (shistocyte) shape. Initially, by day 5 to 10 , red cells get spicules on the surface of their membranes. ${ }^{100}$ These spicules fall off, and the cells become rounded (spherocytes) but also swell and lose their flexibility. They lose approximately $15 \%$ to $20 \%$ of their cell membrane phospholipids by day 15 to $28 .{ }^{100}$ As the red cells survive in their anoxic environment, they lose their Na-K ATPase function, and become edematous. With cell swelling and loss of lipid membrane material, red cells become very stiff and quite friable. They are prone to early destruction, and, if cytokines are present, they are rapidly sequestered and have a shortened circulating half-life.
The combined effects of low $\mathrm{P}_{50}$, dysfunctional cell flexibility, bizarre cellular shapes, and erythrocyte clumping means that banked blood is very poor at perfusing the capillary microcirculation. Studies examining blood flow to the microcirculation have shown that when stored red cells are used, there is a dramatic reduction of flow. In rat models of hemorrhagic shock, both the mesenteric blood flow and the hippocampal blood flow are only reestablished with fresh blood. ${ }^{101,102}$ Stored rat blood to resuscitate hemorrhagic shock only leads to a $10 \%$ restoration of flow.

Stored erythrocytes take up oxygen, but are not efficient in patients after coronary artery bypass surgery grafting surgery: no increase in oxygen delivery to the microcirculation results from transfusion of 1 or 2 units of blood. ${ }^{101}$ Furthermore, in some critically ill patients, it has been shown that transfusing banked blood actually decreases gut oxygen delivery, making the tissues more acidotic. ${ }^{102,103}$

Available evidence shows that RBC transfusion is not associated with improvements in clinical outcome in the critically ill and may result in worse outcomes in some patients. Lack of efficacy of RBC transfusion is likely to be related to storage time, increased endothelial adherence of stored RBCs, nitric oxide binding by free hemoglobin in stored blood, donor leukocytes, host inflammatory response, and reduced red cell deformability.

\section{TRANSFUSION-ASSOCIATED RISKS}

Transfusion-related risks can be divided into transfusion-transmissible infections, immunological risks, and mistransfusion.

\section{Infectious risks}

Red blood cell transfusion in developed countries has probably never been safer than today with respect to transfusion-transmissible viruses such as HIV, hepatitis B virus, and hepatitis $\mathrm{C}$ virus. ${ }^{105}$ In these countries, the estimated risks of infection have dramatically decreased over recent years as increased test sensitivity has reduced the infectious window periods. In contrast, viral infections are still a major problem in developing countries. ${ }^{105} \mathrm{~A}$ high seroprevalence of these diseases in the general population of these countries, poor blood donation systems, and poor sensitivity of pathogen testing are important factors. During the last decades of the twentieth century, substantial scientific and lay press attention was focused on infectious risks including transfusion-associated hepatitis B and C, HIV, West Nile virus, and Variant Creutzfeldt-Jakob disease. With the addition of heightened donor screening and antibody, antigen, and/or nucleic acid testing, many of the 
concerns regarding transfusion-transmission of infectious diseases have been well addressed and largely mitigated or eliminated. Compared with viral infections, at he time of writing there is much more concern about transfusion-transmitted bacterial infections and post-transfusion sepsis.

A significant association between the number of RBC transfusions and subsequent infection has been reported in patients following trauma, burns, and a variety of surgical procedures, both elective and emergency. ${ }^{105,106} \mathrm{~A}$ recent meta-analysis ${ }^{106}$ with 13,152 patients has demonstrated the relationship of allogeneic blood transfusion to postoperative bacterial infection using 20 peer-reviewed studies published from 1986 to 2000. The common odds ratio for the risk of infection associated with RBC transfusion in this meta-analysis was 3.45 (range, 1.43 to 15.15 ), with 17 of the 20 studies demonstrating a value of $P \mathrm{~d}$ " .05 . These results provide overwhelming evidence that RBC transfusion is associated with a significantly increased risk of postoperative bacterial infection in the surgical patient. Similarly, in the critically ill, Taylor et al have demonstrated an association between RBC transfusion and nosocomial infection and mortality. ${ }^{107}$

These data in turn have led to the hypothesis that transfusing patients with leukoreduced blood should result in reduced morbidity and mortality compared with patients receiving nonleukoreduced transfusions. Meta-analyses of the literature have failed to identify a statistically significant effect of leukoreduction ${ }^{108,109}$ on outcomes associated with blood transfusion. A recent study evaluating clinical outcomes following the institution of a universal pre-storage leukoreduction program in Canada noted a reduction in hospital mortality following introduction of this program. ${ }^{110}$ On the other hand, a randomized prospective study comparing outcomes in patients $(n=2,780)$ receiving either leukoreduced or nonleukoreduced RBCs failed to demonstrate any beneficial effect of leukoreduction on clinical outcome, including in-hospital mortality, ICU length of stay or readmission rates, or antibiotic usage. ${ }^{111}$

Recently, the first possible cases of transfusion-transmitted variant Creutzfeld-Jakob disease have been reported. ${ }^{112}$

\section{Immunological risks}

Red cell transfusion with allogeneic blood is a profoundly inflammatory mixture. ${ }^{113-116}$ It contains high levels of a many different cytokines, bradykinin, serotonin, and living white cells. A large body of literature exists showing a relationship between the infusion of red cells in transfusion and early postoperative increased rates of infection. ${ }^{117-120}$ Such infections manifest as wound infections, higher pneumonia rates, dehiscence, and, in orthopedic joint replacements, osteomyelitis.

In years past when early renal transplantation was being developed, it was the practice of those performing renal transplants to give every patient a transfusion because they were aware of the immunosuppressive effects of blood. ${ }^{118}$ Indeed, patients who received transfusion at the time of surgery had fewer acute and chronic rejection episodes. It has been estimated that a single unit of packed red blood cells that is not leukoreduced provides the same immunosuppression as a dose of cyclosporine. Conversely, transfusion at, or immediately after, colon resection for colon cancer has been widely investigated, and shows a relationship between transfusion and early metastasis and also early death. The same has not been shown in other cancers such as prostate cancer, but probably the same mechanisms of immunosuppression that led to more perioperative infection may also lead to the potential implantation or growth of metastatic cell implants.

Engoren et al $^{121}$ quoting from their database with regard to both long- and short-term death rates in relationship to transfusion report a relationship of transfusion use to death rate in more than 1900 coronary artery bypass patients followed up for 60 months. Patients who had transfusion at or near the time of their operation had at least twice the death rate as those not having it, and the Kaplan-Meier survival curves continued to diverge all the way out to 5 years after surgery.

It has been documented that blood transfusion is a risk factor for the development of multiple organ failure and worse outcome in trauma and surgical patients. In a prospective study, Zallen et al further documented an independent risk factor for post-injury multiple organ failure associated to the age of RBCs transfused during the first 6 hours of treatment. ${ }^{114}$ Multivariate analysis identified mean age of blood, number of units older than 14 days, and number of units older than 21 days as independent risk factors for multiple organ failure. One hypothesis is that stored RBCs (older than 14 days) can prime polymorphoneutrophils (PMNs) and thereby provoke multiple organ failure. A recent in vitro study documented that plasma from 42-day-old RBCs stimulated significant release of interleukin (IL)- 8 and secretory phospholipase A2 by PMNs as compared with controls and fresh plasma (day 0).$^{115}$ Emerging data therefore indicate that transfused blood is an inflammatory agent capable of producing PMN priming that may promote organ dysfunction.

Transfusion-related acute lung injury (TRALI) is now considered to be the second leading cause of mortality from transfusion and has emerged as the leading cause of transfusion-related deaths reported to the US Food and Drug 
Administration, though this is most likely because of increased recognition and may in fact represent an overdiagnosis. ${ }^{85}$ It has been associated with various blood products including whole blood, packed red blood cells, apheresis, or whole blood-derived platelets, fresh frozen plasma, granulocytes, intravenous immunoglobulin, and cryoprecipitate. ${ }^{85}$

The first cases of what was likely to have been TRALI appeared in the literature in the early 1950s, and approximately 20 years later an association with leukoagglutinins was suspected as the cause. ${ }^{122}$ It was still another 15 years before the first case series was published ${ }^{122}$ with diagnoses based on clinical symptoms. In fact, it was not until 2003 that clinical criteria were proposed in which an agreed-upon diagnosis of TRALI could be proffered.

Clinically, patients who have TRALI present with a syndrome that can be characterized as having noncardiogenic pulmonary edema with dyspnea, acute hypoxemia, hypotension, and occasionally fever. ${ }^{123}$ Bilateral infiltrates are usually described on chest radiograph; however, because of interpretation, type of study, and patient positioning, this can be variable. Signs of congestive heart failure (increased jugular venous pressure and/or a third heart sound) are usually absent. The pulmonary capillary wedge pressure is typically normal. Symptoms usually appear 1 to 6 hours after transfusion and resolve in less than 48 hours.

In May 2003, the National Heart, Lung, and Blood Institute (NHLBI) convened a working group that sought to develop a common definition of TRALI. ${ }^{122,124}$ They started with the American-European Consensus Committee's definition (acute hypoxemia with $\mathrm{PaO}_{2} / \mathrm{FIO}_{2}$ ratio d" $300 \mathrm{~mm}$ $\mathrm{Hg}$ for acute lung injury (ALI) [d" $200 \mathrm{~mm} \mathrm{Hg}$ for acute respiratory distress syndrome (ARDS)] or oxygen saturation of d" $90 \%$, and the appearance of bilateral infiltrates in the absence of left atrial hypertension). Then, in their definition, cases of new ALI occurring within 6 hours of transfusion in patients who have no other risk factors for lung injury are classified as TRALI. When additional risk factors for ALI other than transfusion are present, the diagnosis of TRALI is made based on temporal association with transfusion and clinical course. TRALI is defined as: (1) a new occurrence of acute onset ALI (with hypoxemia and bilateral infiltrates on chest radiograph but no evidence of left atrial hypertension), (2) not preexisting, but (3) emerging during or within 6 hours of the end of the transfusion, and (4) having no temporal relationship with an alternative TRALI risk factor. ${ }^{122,124}$

Popovsky and Moore ${ }^{125}$ reported 36 cases of TRALI in 1985 , with an incidence of $0.02 \%$ per unit and $0.16 \%$ per patient for all blood products. Other more recent studies have reported widely varying incidence rates ranging from
1:432 whole blood units to 1:557 000 per RBC unit. The real incidence of the transfusion-related reactions underpinning TRALI remains unknown. However, increasing awareness among clinicians of the pathologic entity, combined with an evolution of its definition toward including less severe cases, is likely to increase the reported incidence. In fact, the number of TRALI-related fatalities reported to the US Food and Drug Administration from 2001 to 2003 has steadily risen from $1995 ;{ }^{126}$ TRALI is now the most frequently reported cause of transfusion-related death. ${ }^{127}$

The pathophysiological mechanisms of TRALI are incompletely, if at all, understood and have been described as antibody-mediated and non-antibody-mediated, respectively. ${ }^{126,127}$

Broad prevention strategies have been advocated, including deferral of donors with high likelihood of being previously alloimmunized, universal leukoreduction, greater reliance on apheresis platelets, the strict use of "young" units, and the use of washed products. ${ }^{127}$ Each of these strategies has disadvantages, including added cost, the potential to worsen already significant blood supply shortages, and uncertain levels of preventive efficacy. However, some feel that the risk of TRALI warrants these measures.

With the success of reducing the risk of transfusiontransmitted infectious diseases, serious noninfectious hazards of transfusion have come to the forefront with respect to transfusion safety. Improved understanding of its pathophysiology is needed to improve clinical strategies to deal with the risk. Such understanding, in turn, will depend on the continued progress in development of good model systems, in vitro and in vivo, for experimental studies. Finally, as the pathologic mechanisms are elucidated, a universal definition and strategies for the prevention and/or mitigation may become more feasible.

\section{Mistransfusion}

Mistransfusion is estimated to occur in 1:14 000 to 1:18 000 transfusions and thus is one of the most frequent transfusion hazards, associated with significant morbidity and mortality. ${ }^{122}$

\section{CONCLUSIONS AND PERSPECTIVES}

Widespread concern about complications associated with RBC transfusion has led to the scrutiny of traditional transfusion practices. Recently, attempts have been made to evaluate the efficacy of RBC transfusion and thereby to more clearly define the indications for RBC transfusions in patients, particularly those who are critically ill. Al- 
though available studies about transfusion are very comprehensive, most are only observational studies and therefore do not strongly assist clinicians in deciding when to transfuse. Nevertheless, some important lessons can be learned from these studies. The first is that anemia is extremely common in critically ill patients and therefore is almost to be expected.

The second lesson is that very often the only reason for giving a blood transfusion to patients is that they have a low hemoglobin value. One must assume that these transfusions are given with the hope of improving oxygen delivery in some way. However, usually it is not possible to determine oxygen delivery and tissue extraction adequately.

The third lesson is that allogeneic blood transfusion may be injurious to patients. The associations found in these studies between more units transfused and evidence of worse outcome is not unexpected. Over the years, an increasing volume of data seem to indicate that there are significant harmful effects of blood transfusions.

As mentioned earlier, a hemoglobin-based transfusion trigger does not take into account the individual patient's ability to tolerate and compensate for anemia. Therefore, appropriate transfusion guidelines should be based primarily on physiological transfusion triggers, whereas hemoglobin-based transfusion triggers should serve as an aid in cases of insufficient or unreliable information on the patient's global or regional tissue oxygenation. We must move away from "triggers" to individualize transfusion practices. Global signs of inadequate oxygenation are hemodynamic instability, oxygen extraction $\left(\mathrm{O}_{2} \mathrm{ER}\right)>50 \%$, a mixed venous oxygen saturation $\left(\mathrm{SVO}_{2}\right)<50 \%$, a low mixed venous oxygen partial pressure $\left(\mathrm{PVO}_{2}\right)$, decrease in $\mathrm{VO}_{2}$ and evidence of myocardial ischemia.

The adoption of available blood conservation techniques, either alone or in combination, could result in reduction of unnecessary transfusions and in lower risk. Alternative methods of conservation include meticulous hemostasis in surgical patients, ${ }^{129}$ erythropoietin administration, ${ }^{130,131}$ use of factor VIIa ${ }^{132}$ or desmopressin, ${ }^{133}$ use of hemodilution, ${ }^{134}$ reduction of phlebotomy losses, and reduction of trigger.

From the pooled data regarding the efficacy of RBC transfusions in the critically ill, conservative RBC transfusion strategies in critical care have reduced the risk of transfusion-related adverse effects. The TRICC trial has established the safety of a restrictive strategy, suggesting that physicians could minimize exposure to allogeneic RBCs by lowering their transfusion threshold. Additional studies will be necessary to identify patients who will improve from RBC transfusion and to determine the effects of RBC storage time and the presence of allogeneic leukocytes in allogeneic RBCs.

\section{RESUMO}

Hajjar 1, Auler Junior JOC, Santos L, Galas F. Transfusão de sangue em pacientes críticos: estado da arte. CLINICS. 2007;62(4):507-24.

A transfusão no paciente crítico vem sendo alvo de discussões recentes considerando seus reais benefícios na redução de morbi-mortalidade e os riscos associados ao procedimento. Nos últimos anos, alguns estudos controlados e randomizados tiveram como objetivo comparar desfechos clínicos entre pacientes que receberam transfusão de maneira mais liberal (hemoglobina alvo em torno de $9 \mathrm{~g} / \mathrm{dL}$ ) e transfusão de maneira mais restritiva (hemoglobina em torno de $7 \mathrm{~g} / \mathrm{dL}$ ). Os resultados demonstram a não superioridade da estratégia liberal comparada com a restritiva. Além disso, em alguns subgrupos de pacientes menos graves ou de menor idade, a transfusão foi associada com piores desfechos clínicos. Os riscos da transfusão de sangue no paciente crítico incluem desde incidência maior de infecções bacterianas, infecções virais, imunodepressão, re- ações hemolíticas e lesões teciduais inflamatórias, dentre outros. Algumas estratégias vêm sendo analisadas com o objetivo de redução dos riscos da transfusão e incluem leucorredução, implementação de medidas visando minimizar o tempo de estocagem entre outras. Consensos e recomendações recentes sugerem estratégia restritiva transfusional, estimulando uma prática que visa minimizar as perdas sanguíneas, reduzir o limiar crítico da hemoglobina, detectar anemia e tratá-la, e utilizar estratégias à transfusão, como o uso de antifibrinolíticos e da eritropoietina. $\mathrm{O}$ objetivo dessa revisão é avaliar à luz dos conhecimentos atuais as evidências em torno da transfusão no paciente crítico em diferentes situações, propondo a racionalização das indicações de transfusão, considerando metas a serem atingidas, com o objetivo de minimizar a morbi-mortalidade do paciente crítico.

UNITERMOS: Anemia, Transfusão, Pacientes Críticos, Entrega do oxigênio, Resultados. 


\section{REFERENCES}

1. Hardy JF. Current status of transfusion triggers for red blood cell concentrates. Transfusion and Apheresis Science. 2004;31:55-66.

2. Spiess BD. Red cell transfusions and guidelines: a work in progress Hematol Oncol Clin North Am. 2007;21:185-200.

3. Goodnough LT, Brecher ME, Kanter MH, AuBuchon JP. Transfusion medicine. First of two parts-blood transfusion. N Engl J Med. 1999;340:438-47.

4. Madjpour C, Spahn DR. Allogeneic red blood cell transfusions: efficacy, risks, alternatives and indications. British J Anaesth. 2005; $95: 33-42$.

5. Corwin HL. Anemia and red blood cell transfusion in the critically ill. Seminars in Dialysis. 2006;19:513-6.

6. Starr D. Blood an epic history of medicine and commerce. Harper Collins Publishers: New York; 2002.

7. Corwin HL, Sturgenor S, Gettinger A. Transfusion practice in the critically ill. Critical Care Med. 2003;31:S668-S671.

8. Vincent JL, Baron JF, Reinhart K, Gattinoni L, Thijs L, Webb A, et al Anemia and blood transfusion in critically ill patients. JAMA. 2002;288:1499-507.

9. Corwin HL, Gettinger A, Andrew MD, Pearl RG, Fink M, Levy M et al. The CRIT Study: Anemia and blood transfusion in the critically illcurrent clinical practice in the United States. Crit Care Med. 2004;32:39-52.

10. Ba VN, Bota DP, Melot C, Vincent JL. Time course of hemoglobin concentrations in nonbleeding intensive care unit patients. Crit Care Med. 2003;31:406-10.

11. Vincent JL, Piagnerelli M. Transfusion in the intensive care unit. Crit Care Med. 2006;34:S96-S101.

12. Jelkmann WE, Fandrey J, Frede S, Pagel H. Inhibition of erythropoietin production by cytokines. Implications for the anemia involved in inflammatory states. Ann N Y Acad Sci. 1994;718:300-9.

13. Jelkmann W, Hellwig-Buergel T. Tumor necrosis factor p55 receptor (TNF-RI) mediates the in vitro inhibition of hepatic erythropoietin production. Exp Hematol. 1999;27:224-8.

14.. Zamai L, Secchiero P, Pierpaoli S, Bassini A, Papa S, Alnemri ES, et al. TNF-related apoptosis-inducing ligand (TRAIL) as a negative regulator of normal human erythropoiesis. Blood. 2000;95:3716-24.

15. Krafte-Jacobs B, Levetown ML, Bray GL, Ruttimann UE, Pollack MM. Erythropoietin response to critical illness. Crit Care Med. 1994;22:8216

16. Rogiers P, Zhang H, Leeman M, Nagler J, Neels H, Melot C, et al. Erythropoietin response is blunted in critically ill patients. Intensive Care Med. 1997;23:159-2.

17. DeAngelo AJ, Bell DG, Quinn MW, Long DE, Quellette DR, et al. Erythropoietin response in critically ill mechanically ventilated patients: a prospective observational study. Crit Care. 2005;9:R172-R176.

18. Vincent JL, Sakr Y, Creteur J. Anemia in the intensive care unit. Can J Anaesth. 2003;50:S53-S59.
19. Piagnerelli M, Zouaoui Boudjeltia K, Brohee D, Vereerstraeten A, Piro $\mathrm{P}$ et al. Alterations of red blood cell shape and sialic acid membrane content in septic patients. Crit Care Med. 2003;31:1052-61.

20. Sakr Y, Sprung C, Ranieri MV, Reinhart K, Gerlach H, Moreno R. Sepsis in European intensive care units: results of the SOAP study. Crit Care Med. 206;34:344-53

21. Bucova M, Mistrik M. Transfusion-induced immunomodulation and infectious complications. Vnitr Lek. 2006;52:1085-92.

22. Quellet DR. The impact of anemia in patients with respiratory failure. Chest. 2005;128:576-682.

23. Yoshida T, Aubuchon JP, Tryzelaar L, Foster KY, Bitensky MW Extended storage of red blood cells under anaerobic conditions. Vox Sang. 2007;91:22-31.

24. Hébert PC, Wells G, Blachman MA, Marshall J, Martin C, Pagliarello $\mathrm{G}$, et al. A multicenter, randomized, controlled clinical trial of transfusion requirements in critical care. N Eng J Med. 1999;340:40917.

25. Carson JL, Duff A, Poses RM, Berlin JA, Spence RK, Trout R, et al Effect of anaemia and cardiovascular disease on surgical mortality and morbidity. Lancet. 1996;348:1055-60.

26. Carson JL, Noveck H, Berlin JA, Gould SA. Mortality and morbidity in patients with very low postoperative $\mathrm{Hb}$ levels who decline blood transfusion. Transfusion. 2002;42:812-8.

27. Weiskopf RB, Viele MK, Feiner J, Lieberman J, Noorani M, Leung $\mathrm{JM}$, et al. Human cardiovascular and metabolic response to acute, severe isovolemic anemia. JAMA. 1998;279:217-21.

28. Leung JM, Weiskopf RB, Feiner J, Hopf HW, Kelley S, Viele M et al. Electrocardiographic ST-segment changes during acute, severe isovolemic hemodilution in humans. Anesthesiology. 2000;93:100410.

29. Hébert PC, Wells G, Tweeddale M, Martin C, Marshall J, Pham B, et al Does transfusion practice affect mortality in critically ill patients? Transfusion Requirements in Critical Care (TRICC) Investigators and the Canadian Critical Care Trials Group. Am J Respir Crit Care Med. 1997;155:1618-23.

30. Habib RH, Zacharias A, Schwann TA, Riordan CJ, Durham SJ, Shah $\mathrm{A}$, et al. Adverse effects of low hematocrit during cardiopulmonary bypass in the adult: should current practice be changed? J Thorac Cardiovasc Surg. 2003;125:1438-50.

31. Walsh TS, Saleh Ezz-El-Din. Anemia during critical illness. British Journal of Anesthesia. 2006;97:278-91.

32. Walsh TS, McArdle F, McLellan SA, Maciver C, Maginnis M, Prescott $\mathrm{RJ}$, et al. Does the storage time of transfused red blood cells influence regional or global indexes of tissue oxygenation in anemic critically ill patients? Crit Care Med. 2005;32:100-9.

33. Dellinger RP, Carlet JM, Masur H, Gerlach H, Calandra T, Cohen J et al. Surviving sepsis campaign guidelines for management of severe sepsis and septic shock. Crit Care Med. 2004;32:858-73.

34. Howell PJ, Bamber PA. Severe acute anaemia in a Jehovah's Witness. Survival without blood transfusion. Anaesthesia. 1987;42:44-8. 
35. Madjdpour C, Spahn D, Weiskopf R. Anemia and perioperative blood cell transfusion: a matter of tolerance. Crit Care Med. 2006;34:S102S108.

36. Morisaki H, Sibbald WJ. Tissue oxygenation delivery and the microcirculation. Crit Care Clin. 2004;20:213-23.

37. Hébert PC, Van der Linden P, Biro G, Hu LQ. Physiologic aspects of anemia. Crit Care Clin. 2004;20:187-212.

38. Shoemaker WC, Appel PL, Kram HB. Role of oxygen debt in the development of organ failure sepsis, and death in high-risk surgical patients. Chest. 1992;102:208-15.

39. Bishop MH, Shoemaker WC, Appel PL, Meade P, Ordog GJ, Wasserberger $\mathrm{J}$ et al. Prospective, randomized trial of survivor values of cardiac index, oxygen delivery, and oxygen consumption as resuscitation endpoints in severe trauma. J Trauma. 1995;38:780-7.

40. Velmahos GC, Demetriades D, Shoemaker WC, Chan LS, Tatevossian R, Wo CC. Endpoints of resuscitation of critically injured patients:normal or supranormal? A prospective randomized trial. Ann Surg. 2000;232:409-18.

41.. Kern JW, Shoemaker WC. Meta-analysis of hemodynamic optimization in high-risk patients. Crit Care Med. 2002;30:1686-92.

42. Alia I, Esteban A, Gordo F, Lorente JA, Diaz C, Rodriguez JA. A randomized and controlled trial of the effect of treatment aimed at maximizing oxygen delivery in patients with severe sepsis or septic shock. Chest. 1999;115:453-61.

43. Gattinoni L, Brazzi L, Pelosi P, Latini R, Tognoni G, Pesenti A. A trial of goal-oriented hemodynamic therapy in critically ill patients. $\mathrm{SVO}_{2}$ Collaborative Group. N Engl J Med. 1995;333:1025-32.

43. Heyland DK, Cook DJ, King D, Kernerman P, Brun-Buisson C. Maximizing oxygen delivery in critically ill patients: a methodologic appraisal of the evidence. Crit Care Med. 1996;24:517-24.

44. Shah DM, Gottlieb ME, Rahm RL, Stratton HH, Barie PS, Paloski WH. Failure of red blood cell transfusion to increase oxygen transport or mixed venous $\mathrm{PO}_{2}$ in injured patients. J Trauma. 1982;22:741-6.

45. Hardy JF, Belisle S. Current information on the benefits of allogeneic blood. Transfus Altern Transfus Med. 2000;2:27-32.

46. Consensus Conference. Perioperative red blood cell transfusion. J Am Med Assoc. 1988;260:2700-3.

47. Corwin HL, Parsonnet KC, Gettinger A. RBC transfusion in the ICU. Is there a reason? Chest. 1995;108:767-71.

48. Hébert PC, Wells G, Martin C, Tweeddale M, Marshall J, Blajchman M. A Canadian survey of transfusion practices in critically ill patients. Transfusion Requirements in Critical Care Investigators and the Canadian Critical Care Trials Group.Crit Care Med. 1998;26:482-7.

49. Carson JL, Hill S, Carless P, Hébert PC, Henry D. Transfusion triggers: a systematic review of the literature. Trans Med Rev. 2002;16:187-99.

50. Rivers E, Nguyen B, Havstad S, Ressler J, Muzzin A, Knoblich B, et al. Early goal-directed therapy in the treatment of severe sepsis and septic shock. New England Journal of Medicine. 2001;345:1368-77.

51. Steiner ME, Despotis GJ. Transfusion algorithms and how they apply to blood conservation: the high-risk cardiac surgical patient. Hematol Oncol Clinics of North America. 2007;21:141-67.
52. Levy J.H., Pifarre R, Schaff HV, Horreo JC, Albus R, Spiess B, et al. A multicenter, double-blind, placebo-controlled trial of aprotinin for reducing blood loss and the requirement for donor-blood transfusion in patients undergoing repeat coronary artery bypass grafting. Circulation. 1995;92:2236-44.

53. Despotis GJ, Avidan MS, Hogue CW Jr, et al. Mechanisms and attenuation of hemostatic activation during extracorporeal circulation. Ann Thorac Surg. 2001;72:S1821-S1831.

54. Nuttall GA, Oliver WC, Santrach PJ, Bryant S, Dearani JA, Schaff HV, et al. Efficacy of a simple intraoperative transfusion algorithm for nonerythrocyte component utilization after cardiopulmonary bypass. Anesthesiology. 2001;94:773-81.

55. Moulton MJ, Creswell LL, Mackey ME, Cox JL, Rosenbloom M, et al Reexploration for bleeding is a risk factor for adverse outcomes after cardiac operations. J Thorac Cardiovasc Surg. 1996;111.:1037-46.

56. Munoz JJ, Birkmeyer NJ, Dacey LJ, Birkmeyer JD, Charlesworth DC, Johnson ER, et al. Trends in rates of reexploration for hemorrhage after coronary artery bypass surgery. Northern New England Cardiovascular Disease Study Group. Ann Thorac Surg. 1999;68:13215.

57. Shander A. Emerging risks and outcomes of blood transfusion in surgery. Semin Hematol. 2004;41 (1 Suppl 1):117-24.

58. Goodnough LT. Risks of blood transfusion. Crit Care Med. 2003;31:S678-S686

59. Stover EP, Siegel LC, Parks R, Levin J, Body SC, Maddi R, et al Variability in transfusion practice for coronary artery bypass surgery persists despite national consensus guidelines: a 24-institution study. Institutions of the Multicenter Study of Perioperative Ischemia Research Group. Anesthesiology. 1998;88:327-33.

60. Moore FA, Moore EE, Sauaia A. Blood transfusion. An independent risk factor for postinjury multiple organ failure. Arch Surg. 1997;132:620-4

61. Weiskopf RB. More on the changing indications for transfusion of blood and blood components during anesthesia. Anesthesiology. 1996;84:498-501.

62. Practice guidelines for perioperative blood transfusion and adjuvant therapies: an updated report by the American Society of Anesthesiologists Task Force on Perioperative Blood Transfusion and Adjuvant Therapies. Anesthesiology. 2006;105:198-208.

63. Saxena S, Wehrli G, Makarewicz K, Sartorelli J, Shulman IA. Monitoring for underutilization of RBC components and platelets. Transfusion. 2001:41:587-90.

64. Wu WC, Rathore SS, Wang Y, Rodford MJ, Krumholz H. Blood transfusion in elderly patients with acute myocardial infarction. N Eng J Med. 2001:345:1230-6.

65. Rao SV, Jollis JG, Harrington RA, Granger CB, Newby LK, Armstrong PW, et al. Relationship of blood transfusion and clinical outcomes in patients with acute coronary syndromes. JAMA. 2004;292:1555-62.

66. Simon TL, Alverson DC, AuBuchon J, Cooper ES, DeChristopher PJ Glenn GC, et al. Practice parameter for the use of red blood cell transfusions: developed by the Red Blood Cell Administration Practice Guideline Development Task Force of the College of American Pathologists. Arch Pathol Lab Med. 1998;122:130-8. 
67. Spahn DR, Schanz U, Pasch T. Perioperative transfusions kriterien. Anaesthesist. 1998;47:1011-20.

68. Leung JM, Weiskopf RB, Feiner J, Hopf HW, Kelley S, Viele M, et al Electrocardiographic ST segment changes during acute, severe isovolemic hemodilution in humans. Anesthesiology. 2000;93:100410 .

69. London MJ, Hollenberg M, Wong MG, Levenson L, Tubau JF, Browner $\mathrm{W}$, et al. Intraoperative myocardial ischemia:localization by continuous 12-lead electrocardiography. Anesthesiology 1988;69:232-41.

70. Bak Z, Abildgard L, Lisander B, Janerot-Sjoberg B. Transesophageal echocardiographic hemodynamic monitoring during preoperative acute normovolemic hemodilution. Anesthesiology. 2000;92:1250-6.

71. Spahn DR, Smith RL, Veronee CD, McRae RL, Hu W, Menius AJ, et al. Acute isovolemic hemodilution and blood transfusion: effects on regional function and metabolism in myocardium with compromised coronary blood flow. J Thorac Cardiovasc Surg. 1993;105:694-704.

72. Moss GS, DeWoskin R, Rosen AL, Levine H, Palani CK. Transport of oxygen and carbon dioxide by hemoglobin-saline solution in the red cell-free primate. Surg Gynecol Obstet. 1976;142:357-62.

73. Trouwborst A, Tenbrinck R, van Woerkens EC. Blood gas analysis of mixed venous blood during normoxic acute isovolemic hemodilution in pigs. Anesth Analg. 1990;70:523-9.

74. Fantoni DT, Otsuki DA, Ambrosi AM, Tamura EY, Auler JO Junior, et al. A comparative evaluation of inhaled halothane, isoflurane, and sevoflurane during acute normovolemic hemodilution in dogs. Anesth Analg. 2005;100:1014-9.

75. Otsuki DA, Cardieri FA, Schimidt AP, Brudniewski M, Fantoni DT, Auler JO Junior, et al. Comparison between intermittent and continuous measurement of cardiac output after acute normovolemic hemodilution in pigs. Artif Organs. 2006;30:458-66.

76. Otsuki DA, Fantoni DT, Margarido CB, Marumo CK, Intelizano T, Pasqualucci CA, et al. Hydroxyethyl starch is superior to lactated Ringer as a replacement fluid in a pig model of acute normovolaemic haemodilution. British Journal of Anaesthesia. 2007;98:29-37.

77. Perin D, Cruz Jr R, Silva E, Poli-de-Figueiredo L. Low hematocrit impairs gastric mucosal $\mathrm{CO}_{2}$ removal during experimental severe normovolemic hemodilution. Clinics. 2006;61:445-452.

78. Bishop MH, Shoemaker WC, Appel PL, Meade P, Ordog GJ, Wasserberger J, et al. Prospective, randomized trial of survivor values of cardiac index, oxygen delivery, and oxygen consumption as resuscitation endpoints in severe trauma. J Trauma. 1995;38:780-7.

79. Velmahos GC, Demetriades D, Shoemaker WC, Chan LS, Tatevossian $\mathrm{R}$, Wo CC, et al. Endpoints of resuscitation of critically injured patients: normal or supranormal? A prospective randomized trial. Ann Surg. 2000;232:409-18.

80. Kern JW, Shoemaker WC. Meta-analysis of hemodynamic optimization in high-risk patients. Crit Care Med .2002;30:1686-92.

81. Alia I, Esteban A, Gordo F, Lorente JA, Dias C, Rodriguez JA, et al. A randomized and controlled trial of the effect of treatment aimed at maximizing oxygen delivery in patients with severe sepsis or septic shock. Chest. 1999;115:453-61.

82. Gattinoni L, Brazzi L, Pelosi P, Latini R, Tognoni G, Pesenti A, et al. A trial of goal-oriented hemodynamic therapy in critically ill patients. $\mathrm{SvO}_{2}$ Collaborative Group. N Engl J Med. 1995;333:1025-32.
83. Heyland DK, Cook DJ, King D, Kernerman P, Brunbuisson C. Maximizing oxygen delivery in critically ill patients: a methodologic appraisal of the evidence. Crit Care Med. 1996;24:517-24.

84. Shah DM, Gottlieb ME, Rahm RL, Stratton HH, Barie PS, Paloski WH, et al. Failure of red blood cell transfusion to increase oxygen transport or mixed venous $\mathrm{PO}_{2}$ in injured patients. J Trauma. 1982;22:741-6.

85. Kahn RC, Zaroulis C, Goetz W, Howland WS. Hemodynamic oxygen transport and 2,3-diphosphoglycerate changes after transfusion of patients in acute respiratory failure. Intensive Care Med. 1986;12(1):225 .

86. Gramm J, Smith S, Gamelli RL, Dries DJ. Effect of transfusion on oxygen transport in critically ill patients. Shock. 1996;5:190-3.

87. Mink RB, Pollack MM. Effect of blood transfusion on oxygen consumption in pediatric septic shock. Crit Care Med. 1990;18:108791.

88. Dietrich KA, Conrad SA, Hébert CA, Levy GL, Romero MD. Cardiovascular and metabolic response to red blood cell transfusion in critically ill volume-resuscitated nonsurgical patients. Crit Care Med. 1990;18:940-4.

89. Lorente JA, Landin L, DePablo R, Renes E, Rodriguez-Dias R, Liste D. Effects of blood transfusion on oxygen transport variables in severe sepsis. Crit Care Med. 1993;21:1312-8.

90. Fernandes Jr CJ, Akamine N, DeMarco FV, De Souza JA, Lagudis S, Knobek E. Red blood cell transfusion does not increase oxygen consumption in critically ill septic patients. Crit Care Med. 2001;5:3627.

91. Conrad SA, Dietrich KA, Hébert CA, Romero MD. Effect of red cell transfusion on oxygen consumption following fluid resuscitation in septic shock. Circ Shock. 1990;31:419-29.

92. Silverman HJ, Tuma P. Gastric tonometry in patients with sepsis. Effects of dobutamine infusions and packed red blood cell transfusions. Chest. $1992 ; 102: 184-8$.

93. Ruokonen E, Takala J, Kari A. Regional blood flow and oxygen transport in patients with the low cardiac output syndrome after cardiac surgery. Crit Care Med. 1993;21:1304-11.

94. Marik PE, Sibbald WJ. Effect of stored blood transfusion on oxygen delivery in patients with sepsis. JAMA. 1993;269:3024-9.

95. Fitzgerald RD, Martin CM, Dietz GE, Doig GS, Potter RF, Ssibbald WJ. Transfusing red blood cells stored in citrate phosphate dextrose adenine-1 for 28 days fails to improve tissue oxygenation in rats. Crit Care Med. 1997;25:726-32.

96. McCullough J. Complications of transfusion. In: McCullough J, editor. Transfusion medicine. New York:McGraw-Hill;1999. p. 337-59.

97. Hogman CF, Knutsen F, Loof H. Storage of whole blood before separation: the effect of temperature on red cell 2,3 DPG and the accumulation of lactate. Transfusion. 1999;39:492-7.

98. Woodson R.D.: Importance of 2,3 DPG in banked blood: new data in animal models. Prog Clin Biol Res. 1982;108:69-78.

99. Hovav T, Yedgar S, Manny N, Barshtein G. Alteration of red cell aggregability and shape during blood storage. Transfusion. 1999;39:277-81. 
100. Fitzgerald RD, Martin CM, Dietz GE, Doig GS, Potter RF, Sibbald WI. Transfusion red blood cells stored in citrate phosphate dextrose adenine- 1 for 28 days fails to improve tissue oxygenation in rats. Crit Care Med. 1997;25:726-32.

101. Tsai A, Cabrales P, Intaglietta M. Microvascular perfusion upon exchange transfusion with stored red blood cells in normovolemic anemic conditions. Transfusion. 2004;44.1626-34.

102. D'Almeida MS, Gray D, Martin C, Ellis CG, Chin-Yee IH. Effect of prophylactic transfusion of stored RBC's on oxygen reserve in response to acute isovolemic hemorrhage in a rodent model. Transfusion. 2001;41:950-6.

103. Suttner S, Piper SN, Kumle B, Lang K, Rohm KD, Isgro F, et al. The influence of allogeneic red blood cell transfusion compared with $100 \%$ oxygen ventilation on systemic oxygen transport and skeletal muscle oxygen tension after cardiac surgery. Anesth Analg. 2004;99:2-11.

104. Auler Junior JO, Bonetti E, Hueb AC, Galas FR, Carmona MJ. Effects of massive transfusion on oxygen availability. Sao Paulo Med J. 1998;116:1675-80

105. Blajchman MA. Immunomodulation and blood transfusion. Am J Ther. 2002;9:389-95.

106. Hill GE, Frawley WH, Griffith KE, et al. Allogeneic blood transfusion increases the risk of postoperative bacterial infection: a meta-analysis. J Trauma. 2003;54:908-14.

107. Taylor RW, Manganaro L, O’Brien J, Trottier SJ, Parkar N, Veremaris C. Impact of allogenic packed red blood cell transfusion on nosocomial infection rates in the critically ill patient. Crit Care Med. 2002;30:224954.

108. Vamvakas EC, Blajchman MA. Deleterious clinical effects of transfusion-associated immunomodulation:fact or fiction. Blood. 2001;97:1180-95

109. Vamvakas EC, Blajchman MA. Universal WBC reduction: the case for and against. Transfusion. 2001;41:691-712.

110. Hébert PC, Fergusson D, Blajchman MA, Wells GA, Kmetic A, Coyle $\mathrm{D}$, et al. Clinical outcomes following institution of the Canadian universal leukoreduction program for red blood cell transfusions. JAMA. 2003;289:1941-9.

111. Dzik WH, Anderson JK, O’Neill EM, Assmann SF, Kalish LA, Stowell CP. A prospective, randomized clinical trial of universal WBC reduction. Transfusion. 2002;42:1114-22.

112. Llewelyn CA, Hewitt PE, Knight RS, Amar K, Cousen S, Mackenzie J, et al. Possible transmission of variant Creutzfeldt-Jakob disease by blood transfusion. Lancet. 2004;363:417-21.

113. Malone DL, Dunne J, Tracy JK, Putman AT, Scalea TM, Napolitano LM. Blood transfusion, independent of shock severity, is associated with worse outcome in trauma. J Trauma. 2003;54:898-905.

114. Zallen G, Offner PJ, Moore EE, Blackwell J, Ciesla DJ, Gabriel J, et al. Age of transfused blood is an independent risk factor for postinjury multiple organ failure. Am J Surg .1999;178:570-2

115. Zallen G, Moore EE, Ciesla DJ, Brown M, Biffl WL, Silliman CC et al. Stored red blood cells selectively activate human neutrophils to release IL-8 and secretory PLA2. Shock. 2000;13:29-33.

116. Blumberg N, Heal JM. Effects of transfusion on immune function. Arch Pathol Lab Med. 1994:118:371-9.
117. Landers DF, Hill GE, Wong KC, Fox IJ. Blood transfusion-induced immunomodulation. Anesth Analg. 1996;82:187-204.

118. Mickler TA, Longnecker DE. The immunosuppressive aspects of blood transfusion. J Intensive Care Med. 1992;7:176-88.

119. Blajchman MA. Immunomodulation and blood transfusion. Am J Ther. 2002;9:389-95.

120. Hill GE, Frawley WH, Griffith KE, Forestner JE, Minei JP. Allogeneic blood transfusion increases the risk of postoperative bacterial infection a meta-analysis. J Trauma. 2003;54:908-14

121. Engoren MC, Habib RH, Zacharias A, Schwann TA, Riordan CJ, Durham SJ. Effect of blood transfusion on long-term survival after cardiac surgery. Ann Thorac Surg. 2002;74:118-6.

122. Despotis GJ, Zzhang L, Lublin DM. Transfusion risks and transfusionrelated proinflammatory responses. Hematol Oncol Clin N Am. 2007;21:147-61

123. Looney MR, Grooper MA, Matthay MA. Transfusion-related acute lung injury: a review. Chest. 2004;126:249-58.

124. Silliman CC, Boshkov LK, Mehdizadehkashi Z, Elzi DJ, Dickey WO, Podlosky L, et al. Transfusion-related acute lung injury: epidemiology and a prospective analysis of etiologic factors. Blood. 2004;101:45462

125. Popovsky MA, Moore SB. Diagnostic and pathogenetic considerations in transfusion-related acute lung injury. Transfusion. 1985;25:573-7.

126. Rubenfeld GD, Caldwell E, Peabody E, Weaver J, Martin DP, Neff M, et al. Incidence and outcomes of acute lung injury. N Engl J Med. 2005;353:1685-93.

127. Holness L, Knippen MA, Simmons L, Lachenbruch PA. Fatalities caused by TRALI. Transf Med Rev. 2004;18:184-8.

128. Kopko PM, Marshall CS, Mackenzie MR, Holland PV, Popovsky MA Transfusion-related acute lung injury: report of a clinical look-back investigation. JAMA. 2002;287:1968-71.

129. Atik FA, Miana LA, Jatene FB, Auler Junior JO, Oliveira SA Myocardial revascularization surgery without extracorporeal circulation minimizes postoperative bleeding and the need for transfusion. Arq Bras Cardiol. 2004;83:338-42.

130. Levy JH. Anti-inflammatory strategies and hemostatic agents: old drugs, new ideas. Hematol Oncol Clin North Am. 2007;21:89-101.

131. Goodnough LT, Shander A, Spence R. Bloodless medicine: clinical care without allogeneic blood transfusion. Transfusion. 2003;43:668 76

132. Despotis G, Avidan M, Lublin DM. Off-label use of recombinant factor VIIA concentrates after cardiac surgery. Ann Thorac Surg. 2005;80:35.

133. Mongan PD, Hosking MP. The role of desmopressin acetate in patients undergoing coronary artery bypass surgery. A controlled clinical tria with thromboelastographic risk stratification. Anesthesiology. 1992;77:38-46.

134. Fraga AO, Fantoni DT, Otsuki DA, Pasqualucci CA, Abduch MC, Auler $\mathrm{Jr} \mathrm{JO}$, et al. Evidence for myocardial defects under extreme acute normovolemic hemodilution with hydroxyethyl starch and lactated ringer's solution. Shock. 2005;24:388-95. 